Estudios de

lingüistica inglesa aplicada

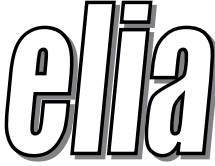

\title{
BILINGUAL EDUCATION IN MINORITY LANGUAGE CONTEXTS: WHEN A HIGH LEVEL OF LINGUISTIC COMPETENCE IS NOT ENOUGH
}

\section{EDUCACIÓN BILINGÜE EN CONTEXTOS DE LENGUA MINORITARIA: CUANDO EL NIVEL DE COMPETENCIA LINGÜÍSTICA NO ES SUFICIENTE}

\section{Pádraig Ó Duibhir}

Dublin City University, Institute of Education, Ireland

padraig.oduibhir@dcu.ie

DOI: http://dx.doi.org/10.12795/elia.mon.2019.i1.03

Much of the debate on bilingualism and interculturality has focused on the cultural and linguistic diversity of indigenous populations in regions such as South America. In Europe and North America, the educational rights of migrant children have been emphasised. The needs of speakers of regional, minority or lesser-used languages have tended to be overlooked and hence received less attention in the literature. The most distinctive differences between minority language speakers and their compatriots are, on the surface at least, linguistic rather than cultural.

This paper explores current discourse and research about the linguistic identity of speakers of minority or lesser-used languages, living in communities where world languages predominate. My background in Irish-medium education in Ireland has been a driving force in questioning and understanding the factors within schools and across the wider 
community and society that influence active bilingualism. In my experience, minority language speakers seek to negotiate a bi-or pluri-lingual identity. The role of minority language education in supporting individual emerging identity is complex. Evidence from the Irish context suggests that while the Irish-medium education system is successful in generating competent bilingual speakers, the graduates of this system don't necessarily become active bilinguals. Power, prestige and status lie with the dominant language and students may consider the minority language redundant with limited function. Emerging evidence suggests that the school environment may have limited influence in shaping teenagers' bilingual identity and this paper will explore why competence is not enough.

Key words: Immersion, minority language, identity, bilingual education, intercultural

Gran parte del debate sobre el bilingüismo y la interculturalidad se ha centrado en la diversidad cultural y lingüistica de las poblaciones indígenas en regiones como América del Sur. En Europa y América del Norte se han enfatizado los derechos educativos de los niños migrantes. Las necesidades de los hablantes de lenguas regionales, minoritarias o menos usadas a menudo se han pasado por alto $y$, por lo tanto han recibido menor atención en las investigaciones. Las diferencias más significativas entre los hablantes de lenguas minoritarias y sus compatriotas son, al menos en apariencia, diferencias lingüísticas más que culturales.

Este artículo explora la discusión actual y la investigación sobre la identidad lingüistica de los hablantes de lenguas minoritarias o menos utilizadas, que viven en comunidades donde predominan lenguas de alcance mundial. Mi experiencia en la educación secundaria irlandesa en Irlanda ha sido el detonante para cuestionar y tratar de comprender los factores que inciden sobre este fenómeno, dentro de las escuelas, en la comunidad y en la sociedad en general y que influyen sobre el bilingüismo activo. De acuerdo con mi experiencia, los hablantes de lenguas minoritarias tratan de negociar una identidad bilingüe o plurilingüe. El papel de la educación de lenguas minoritarias como apoyo a la identidad emergente individual es complejo. La evidencia del contexto irlandés sugiere que si bien un sistema educativo con el irlandés como lengua vehicular consigue generar hablantes bilingües competentes, estos no se convierten necesariamente en bilingües activos. El poder, el prestigio y el

ELIA Mon. I, pp. 39-64 DOI: http://dx.doi.org/10.12795/elia.mon.2019.i1.03 
estatus forman parte de la lengua dominante y los estudiantes pueden considerar que el idioma minoritario es redundante con una función limitada. Los últimos descubrimientos sugieren que el entorno escolar probablemente tenga una influencia limitada en la configuración de la identidad bilingüe de los adolescentes y este artículo explorará por qué su nivel de competencia no es suficiente.

Palabras clave: Inmersión, lengua minoritaria, identidad, educación bilingüe, intercultural

\section{Introduction}

The civil rights movements of the 1960s led to a greater awareness of linguistic rights among minority language communities. Article 27 of the International Covenant on Civil and Political Rights, states that recognised minorities "shall not be denied the right, in community with the other members of their group, to enjoy their own culture ... to use their own language" (United Nations, 1966). This increased awareness of language rights resulted in demands for greater support for minority languages in education. This was, in part, a reaction to the predominant monolingual paradigm found in the majority of schools in Europe which had evolved as a legacy of nation-building processes (Busch, 2011). Many jurisdictions such as Wales, Scotland, Ireland, the Basque Country and the Valencian Country experienced renewed growth in minority language education from the 1970's onwards and adopted what became known as one-way minority language immersion programmes (Ó Duibhir, 2018). In the Spanish context, for example, a considerable proportion of Spanish-speaking students attend schools where a regional language such as Catalan/ Valencian, Galician or Basque is the main language of schooling. These strong forms of bilingual education seek to rebalance the dominance of the majority language in society by educating the next generation in the minority language and reversing language shift where possible.

\section{Bilingual Education}

There are many forms of bilingual education that aim for additive bilingualism, to develop proficiency in a minority and a majority language

ELIA Mon. I, pp. 39-64 DOI: http://dx.doi.org/10.12795/elia.mon.2019.i1.03 
simultaneously, with the option of adding third and fourth languages. These bilingual programmes described by Baker and Wright (2017) as strong forms of bilingual education, might be immersion or maintenance programmes. The linguistic context varies enormously in each jurisdiction, making comparison difficult. It is helpful therefore, to consider at this point, the Continua of Multilingual Education Model (Figure 1) developed by Cenoz (2009). In Cenoz's model, three distinct elements are identified. The first is 'linguistic distance' and this refers to the degree of similarity and difference between two languages. Spanish and Catalan, for example, are considered relatively close, making some conversations mutually intelligible because the languages share vocabulary, syntactic structure, phonology etc. Basque and Spanish on the other hand are very different in terms of vocabulary and grammar. They do, however, share some similarities at the phonological and pragmatic level (Cenoz, 2009). Less distant languages are thought to be easier to learn.

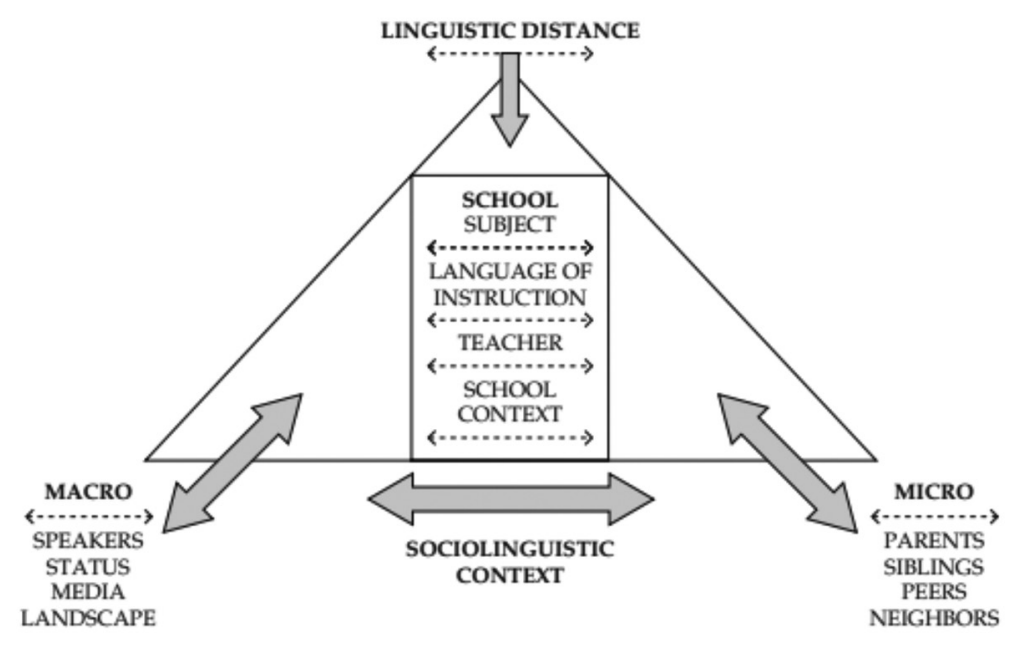

Figure 1. Continua of Multilingual Education Model. (Cenoz, 2009)

The second main element in Cenoz's model is the sociolinguistic context with both 'macro' and 'micro' levels. The macro level refers to the linguistic vitality of the language which includes the number of speakers of the language, its status in society, its use in the media and in the linguistic 
landscape. The micro level encompasses the use of the language in the home with parents, siblings and extended family, and the use of the language with peers in the community. Within the school, a minority language might be taught as a subject, or it could be the language of instruction ensuring greater exposure to and use of the language. Teachers may teach the language only, or they may teach content through the language. The school context could promote the use of the minority language as a means of communication outside the classroom or its use may be limited to the classroom.

Minority language educational contexts may appear broadly similar, but the linguistic practices of the students will be greatly influenced by the macro and micro factors. Students who live in bilingual communities (where the minority language is supported at a macro level) are more likely to speak the minority language outside the school compared to their peers who live in predominantly majority language communities. This difference in minority language use is seen even when curriculum provision and contact with the minority language is similar in both settings. The weaker the macro level support the bigger the gap between competence and language use.

\section{The Gap between Minority Language Competence and Use}

One of the greatest challenges in minority language acquisition, is to provide opportunities for language use at both the macro and micro level. In many regions (e.g. Ireland, Wales, Scotland, Basque Country and Valencian Community), minority language speakers are in regular or consistent contact with a majority language which they also speak. Where the number and concentration of minority language speakers are small, or where there may be no monoglot speakers of the minority language, a reduced communicative need to use the minority language results ( $\mathrm{Cenoz}$ $\&$ Gorter, 2019). It is widely accepted that the education system is a critical context in the revival and strengthening of minority languages (Fishman, 1991; Hornberger, 2008; Manterola, Almgren, \& Idiazabal, 2013). It is equally accepted, but sometimes forgotten, that schools on their own cannot revive a minority or threatened language (Baker, 2003; Manterola, 2013; McCarty, 2008; Skutnabb-Kangas, 2008). Drawing on Cenoz's (2009) model above, schools do not exist in a sociolinguistic vacuum and need to be supported at state (macro) and community (micro) level where,

ELIA Mon. I, pp. 39-64 DOI: http://dx.doi.org/10.12795/elia.mon.2019.i1.03 
at the very least, students can come into contact with the language and have opportunities to use the language for meaningful communication.

Grin (2003) suggests that three elements are required to promote greater minority language use. The first, is capacity or language competence. This element is possibly the easiest to achieve through bilingual education and depends to some degree on the linguistic distance between the minority and the majority language. The second is opportunity to use the language, which has been discussed above and reflects Cenoz's assertion that support at a macro level in the society is needed. The third, a desire or willingness to use the language is influenced by the individual learner's exposure to the language within their immediate social circle (micro level) and language status (macro level).

Education contexts tend to address language capacity or competency but have a more limited influence on opportunity and desire. Language competency will be influenced by factors such as the intensity of the language programme within the school and the linguistic distance between the target language and previously acquired languages. The macro and micro factors impact opportunities and desire to use the language outside school. The sociolinguistic context outside the school must be supported and managed by state language planning policies. Without adequate state endorsement for structured programmes, there is a real danger that the minority language learned in school will not transfer to wider society. This is not because the students have inadequate linguistic competence. We know that even when linguistic competence is high, the absence of opportunities to use the minority language results in the status of the language being diminished and this may ultimately impact the student's desire to use the minority language. Grin (2003) suggested that the state has a vital role to play in creating opportunities for language use outside the private sphere of the home through its language policies. The discourse, however, in the revival of some minority language contexts such as Ireland is limited almost exclusively to the school and linguistic competence. There has been an ongoing assumption that as competent bilinguals emerge from the education system, Irish will become more widely spoken (Government of Ireland, 1987). The challenge that arises for those competent bilinguals with a positive attitude to speaking the language is that there is no easily accessible speech community for them to participate in. So, they do not have opportunities to use the minority language.

ELIA Mon. I, pp. 39-64ＤOI: http://dx.doi.org/10.12795/elia.mon.2019.i1.03 
Bilingual education can help to provide learners with linguistic capacity but has little control or influence over opportunity.

While a strong relationship has been found between exposure to a target language and the acquisition of linguistic forms (Thomas, Apolloni, \& Lewis, 2014; Thordardottir, 2011), opportunity and desire to speak a minority language are also impacted by target-language exposure. Exposure and opportunities to use the language in domains outside of school such as family, peer group and society in general are crucial if revitalisation efforts are to be successful (Fishman, 2013).

To illustrate the competence-use gap, data is presented from selected minority language regions. Most of the macro-level data are drawn from population censuses and are based on self-report data of language proficiency. One needs to be careful in interpreting these data as other factors can influence respondents' self-assessment of their linguistic ability (Ó Riagáin, 2018). Self-assessment of language proficiency is obviously subjective. Some people will rate themselves as being able to speak a language when they possess the ability to say a few words. Others, who speak the language regularly, may not consider themselves able to speak it as it may not be their mother tongue.

\subsection{Basque Country, Spain}

According to the sociolinguistic survey of the Basque Country, the number of people over the age of 16 competent to speak Basque has increased steadily from $24.1 \%(419,000)$ in 1991 to $33.9 \%(613,000)$ in 2016 (Basque Government, 2016, p. 6). Much of this increase in competence can be credited to the increase in Basque-medium education. In 2011, 64.0\% of primary and $58.8 \%$ of post-primary students were attending Model D, Basque-medium schools (Martínez de Luna, Suberbiola, Zalbide, Egaña, \& Ubieta, 2013). Street use of Basque, which is quite a stringent measure of language use compared to census self-report data, was reported as $12.6 \%$ across the Basque Country (Soziolinguistika Klusterra, 2017, p. 5). It is interesting to note again that competence or ability to speak a minority language does not always transfer to use in the community. There may, however, be a greater use of Basque in the home which is not captured in the street-use surveys.

ELIA Mon. I, pp. 39-64 DOI: http://dx.doi.org/10.12795/elia.mon.2019.i1.03 


\subsection{Republic of Ireland}

The latest census data for the Republic of Ireland revealed that 39.8\% (1.76 million) people, aged three and older, responded 'yes' to being able to speak Irish (Central Statistics Office, 2017). Irish is a compulsory subject on the school curriculum for all students at primary and post-primary level. In order to get a true measure of actual use of Irish in society, respondents were asked if they use Irish on a daily or weekly basis outside the education system. In response to this question $1.7 \%(73,803)$ responded that they spoke Irish daily, and a further $2.5 \%(111,473)$ spoke it weekly, outside the education system (Central Statistics Office, 2017). So, while there was a relatively large percentage of the population reporting competence in Irish, only a small number are active daily or weekly users of the language. This represents a very large gap between self-reported competence and language use.

\subsection{Scotland}

In the 2011 census in Scotland (National Records of Scotland, 2013) 1.1\% $(57,602)$ of people, aged three and over, reported being able to speak Gaelic. In terms of daily use, the closest indication we can get is that of the languages other than English used at home, Gaelic was used by $0.5 \%$ (c. 25,000 ) of the population, aged three and over (National Records of Scotland, 2014). When compared to Irish and Welsh, this measure of daily use of Gaelic is quite conservative as people who may not speak Gaelic at home may do so in their employment, leisure or social activities. The figure of $1.1 \%$ being able to speak Gaelic represents a very low level of competence within Scotland and indicates that overall linguistic vitality is quite low. However, almost half of those with Gaelic speak it daily, which is a much higher prevalence than Ireland.

\subsection{Valencian Community, Spain}

In a recent survey of knowledge and social use of the Valencian language it was found that just over half of the respondents could speak Valencian fluently $(33 \%)$ or quite well $(17.9 \%)$ (Generalitat Valenciana, 2015). In relation to use of Valencian it was found that $5 \%$ use Valencian a lot, $21 \%$

ELIA Mon. I, pp. 39-64 DOI: http://dx.doi.org/10.12795/elia.mon.2019.i1.03 
quite often and $28 \%$ usually. These figures imply that unlike the other minority language jurisdictions reviewed, the gap between knowledge of Valencian and its use is minimal. These figures may reflect greater linguistic vitality for Valencian and less linguistic distance between Valencian and Spanish.

\subsection{Wales}

In both the 2011 Census (Welsh Government, 2012) and the National Survey for Wales, 2017-18 (Welsh Government, 2018) 19\% (562,000) aged 3 or over responded that they could speak Welsh. The most recent Annual Population Survey (APS) (June 2017 to June 2018) reported that $29 \%$ of people aged three or over could speak Welsh. This disparity in figures highlights vagaries of self-report data. Nonetheless, when we examine daily use of Welsh, we find that 13\% $(360,900)$ aged three and over reported speaking Welsh daily. Compared to the similar data from Ireland the gap between competence and daily use is considerably smaller. The Welsh Language Commissioner, Aled Roberts, recently noted that he did not want Welsh language policy to focus on the number of speakers as is the case in Ireland but rather "to focus on plans which will lead to increasing the daily use of the Welsh language" (Roberts, 2019).

In summary, notwithstanding some concerns in relation to the reliability of self-report data, the indicative picture that emerges is one of linguistic competence exceeding language use. While one can always expect that competence will outstrip use to some extent in minority language contexts, the gap is conspicuously large in the case of Ireland, for example. Factors that are likely to impact on the rate of language use are, the utility value of the minority language for speakers in their daily lives, the status in society and overall linguistic vitality (Cenoz, 2009; Landry, Allard, \& Deveau, 2010).

\section{Linguistic Identity}

Where competent bilinguals emerge from the education system, as is the case in the jurisdictions examined above, several questions arise. First, is there a minority language speech community for them to participate in?

ELIA Mon. I, pp. 39-64 DOI: http://dx.doi.org/10.12795/elia.mon.2019.i1.03 
Second, do they have the desire to use the language? Third, what is the distance between the languages in question? The answers to these questions will, most likely, vary from one context to another and may explain the gap between competence and use highlighted above.

Desire to speak the minority language is bound by what Van Lier describes as agency, self and identity (Van Lier, 2010). Minority language learner identity is an under-researched area as it pertains to young learners. The examination of identity is worthwhile here as it provides a measure of what "integrates the individual language learner and the larger social world" (Norton, 2013, p. 2). A sense of identity and of belonging to a specific minority group can be a motivating factor for some although this can differ across minority, heritage, foreign and indigenous language contexts (Hinton, 2011). Identity can be a means to protect difference and resist assimilation in the context of a minority language. Alternatively, it may hamper a desire for integration in the case of a foreign language. Teenagers may reject a minority language, culture and identity in favour of one where a majority language dominates (Groff, Pilote, \& Vieux-Fort, 2016)

Adolescents may see certain contextual advantages relating to particular languages, a viewpoint which ultimately impacts language use. An example of this is seen in the low incidence of minority language use in social media due to the prevalence of the majority language within the same domain (Landry et al., 2010; Stern, 2017). Gender may also impact minority language use among adolescents. In their research on interactions between Welsh adolescents, Thomas and Roberts (2011) found that 91.7\% of interactions among girls were in Welsh while only $69.4 \%$ among boys were in Welsh. Similar patterns are likely to be found elsewhere (DołowyRybińska, 2016; Price \& Tamburelli, 2016).

Social networks have a significant impact on language use among adolescents. This can be a tumultuous time in the life of a young person and can lead to a need for a common, strong and stable identity that can withstand the changes taking place around them. Conformity to particular language behaviours may underpin this identity and provide the required stability. This could include the adoption of phonological innovations to "emphasize differences among themselves" (Eckert, 1988, p. 198) in order to identify themselves with a particular subgroup.

ELIA Mon. I, pp. 39-64 DOI: http://dx.doi.org/10.12795/elia.mon.2019.i1.03 
In cases where the minority language is confined to the educational domain, the language may be viewed narrowly by young people as a symbol of schooling and of formal practice. This is evident in minority language contexts such as Wales, where English may be seen as the language of rebellion among young people (Price \& Tamburelli, 2016) leading to a reluctance to use the minority language outside of the educational domain. In the case of migrant students whose only contact with the minority language is within the educational domain, it is necessary to provide alternative opportunities and domains in which the minority language would be used to optimise and broaden the contexts of language use. In instances of diglossia, where the majority language enjoys a high status as a community language, the minority language consequently may be viewed as having a lower status in society and among the minority language community itself. In these cases, the minority language is seen as a private language enjoying solidarity among members but with little evidence of this solidarity outside of the minority language community itself (Landry et al., 2010). Migrant learners of minority languages for whom the language is solely an educational endeavour may not experience this solidarity and as a result, the functionality of the language and its impact on their identity may be limited (Landry et al., 2010).

Even though a young learner may not be a regular user of the minority language, it cannot be assumed that they do not wish to experience membership of both (or more) language communities or that their identity cannot be impacted by these experiences. This introduces the concept of identity negotiation.

\subsection{Negotiation of Identity}

Landry et al. (2010) discuss identity involvement, an element of ethnolinguistic identity where individuals state what they are "ethnically, linguistically and culturally" (Landry et al., 2010, p. 77). Identity need not necessarily be limited to membership of a single group. Group membership has been found to be very important for teenagers (Eckert, 1988). Negotiation of identities is experienced by teenagers in multilingual contexts (Groff et al., 2016; Pavlenko \& Blackledge, 2004). For instance, a speaker may prefer to identify as a bilingual speaker as opposed to a member of a single linguistic group. Landry et al. (2010) identified three

ELIA Mon. I, pp. 39-64ＤOI: http://dx.doi.org/10.12795/elia.mon.2019.i1.03 
categories of identity involvement in the Canadian context. The first, was the similarities group members feel between themselves. The second, was the collective self-esteem or the pride felt by belonging to a particular group. The third, was the desire to want to defend the rights of the group (Landry et al., 2010, p. 155).

Another example is that of young Breton speakers who relate strongly to a Breton identity due to their participation in Breton schooling. However, they also feel a strong connection to their French identity due to their involvement in domains and practices where that language is prevalent (Dołowy-Rybińska, 2016). According to Landry et al. (2010), "solidarity domains" such as family and social network are particularly important to young speakers. This "spirit of solidarity" is evident also among the Diwan (language immersion) students in Brittany. In this instance, however, linguistic identity is not dependant solely on language use. Knowledge of the Breton language is also seen as a factor underpinning the solidarity felt among young speakers. While they can speak Breton, they often choose to speak French instead. This can lead to feelings of guilt as expressed by a Breton adolescent in the following extract:

For many years we are told that we are responsible and that's what I am afraid of. I worried about this for years. I blamed myself strongly for this. But I think that today ... yes, I feel responsible in a way. But whatever I do, I shouldn't feel guilty for what I am doing. I think that everybody who speaks Breton [has] the responsibility. But it shouldn't be like that and that we feel forced to engage ourselves in this totally. I think that we should do what makes us happy (Dołowy-Rybińska, 2016, p. 286).

Adolescents in other minority language contexts such as Wales have echoed similar feelings of guilt:

They always play the guilt trip [...] "Seven hundred years ago we fought for the Welsh, people died for the Welsh language". Come on, let us just speak it. Don't force it on us. People get angry when Christians force Christianity on you- it's the same with Welsh. (Price \& Tamburelli, 2016, p. 195)

In a study of post-secondary young people in Québec City who spoke a language other than French at home, (Groff et al., 2016, p. 19) there was evidence of a resistance to coercion among participants. "The fact that they

ELIA Mon. I, pp. 39-64 DOI: http://dx.doi.org/10.12795/elia.mon.2019.i1.03 
want to just force people into your [sic] culture is a little much for me". The same participant went on to state: "I know I'm here, but I don't feel 100\% integrated. Because I just don't want to be integrated into this culture as much. I'd rather be in an English-oriented culture".

\subsection{Identity as investment}

A concept similar to identity involvement is the notion of investment. This is a sociological concept that Norton developed to complement the psychological construct of motivation (Norton, 2013). Norton argued that a learner might be highly motivated to learn a language (to pass an exam for example) but have little investment in using the language outside of the classroom and school. We can explore these constructs in the context of the competence use gap described above, where minority languages are successfully acquired in an education context but are not used in the wider community and society. According to Darvin and Norton (2015, p. 46) investment occurs "at the intersection of identity, ideology, and capital". (2015, p. 43). Ideology refers to attitudes, beliefs and values towards language teaching, learning and use. If a language-revitalization project is to be successful, it needs to work within a community to identify and shift linguistic ideologies (Riestenberg \& Sherris, 2018). In a study of immersion students in Québec, Ballinger (2017) found that the status of the language at an individual, classroom and societal level impacted student's minority language use and investment. Building on Pavlenko and Norton's (2007) argument, if learners cannot envision their future selves in an imagined minority language community their agency, motivation, investment, and resistance to speaking the language in unmonitored situations within the school and in the community may be influenced.

When considering capital, we think of the cultural, economic and social benefits of acquiring a new language. While minority language learners may see cultural advantages, they are less likely to see many economic or social advantages in acquiring the minority language if the language does not enjoy a reasonable status in the community or have uses in a number of domains. Within the investment paradigm, students may be motivated but not invested in language learning, if classroom experience is at odds with their identities, ideologies, or perceived relationship to various types of capital.

ELIA Mon. I, pp. 39-64ＤOI: http://dx.doi.org/10.12795/elia.mon.2019.i1.03 
So, we might ask ourselves at this point, what insights does the research provide into minority language use of competent minority language bilinguals? In this final section, the results of research studies conducted by our research group are presented. These studies focused on minority language use among Irish-immersion primary and post-primary students and their parents.

\section{Language use in the Irish context}

A feature of the revitalisation efforts of the Irish language in the Republic of Ireland is that it is a compulsory curriculum subject throughout all years of schooling, typically from $4 / 5$ to $18 / 19$ years of age. The majority of students attend schools where Irish is taught as a subject for 30-40 minutes per day. Approximately $8 \%$ of students at primary level and $4 \%$ at post-primary level attend Irish-medium schools where all content, except English language arts, is taught through the medium of Irish. This represents approximately $84 \%$ instructional time in Irish-medium primary schools. A third or fourth language is added in post-primary school, with all other subject content taught through Irish. Teachers are mostly competent bilinguals, with a small percentage of native speakers. There is an expectation that students speak Irish outside the classroom within the school environs. We know from other contexts, such as Wales, that Welsh-medium students reported greater use of English when a teacher was not present (Thomas et al., 2014). Cenoz and Gorter (2017) reported similar findings for Basquemedium students with the proportion of students complying with school norms decreasing from primary to post-primary school.

Maintaining Irish as a compulsory subject at Senior-Cycle level (age 17-19 years) is the subject of current debate. Many of the arguments in favour of discontinuing compulsory study are motivated by the failure of most students outside of the Irish-medium setting to acquire additional competence in the language after 13-14 years of study. Part of the problem, it could be argued, is that revival efforts to date have been too narrowly focused to the sphere of education, with little or no attention paid to the wider sociolinguistic context. There is an assumption on the part of many in Ireland, that if Irish was taught more effectively in schools, the language would be more widely spoken. A similar assumption applies to graduates of Irish-medium schools. There is an expectation that because they have very

ELIA Mon. I, pp. 39-64 DOI: http://dx.doi.org/10.12795/elia.mon.2019.i1.03 
good communication skills in Irish, students will go on to become active Irish speakers in their adult lives, and in doing so, help to revive Irish.

In a study with colleagues (Ó Duibhir, Ó Cathalláin, NigUidhir, Ní Thuairisg, \& Cosgrove, 2017) the extent to which Irish-medium students $(n=370)$ availed of opportunities to speak Irish outside of class, while in the school environs was examined. Responses to the statement; "To be honest, I don't make much effort to speak Irish outside of the class when I am at school", showed that just over half $(51.2 \%)$ of the primary students and just over a quarter $(25.7 \%)$ of post-primary students disagreed or strongly disagreed with this statement (Figure 2). This suggested that postprimary students made less effort than their primary peers to speak Irish outside of class.

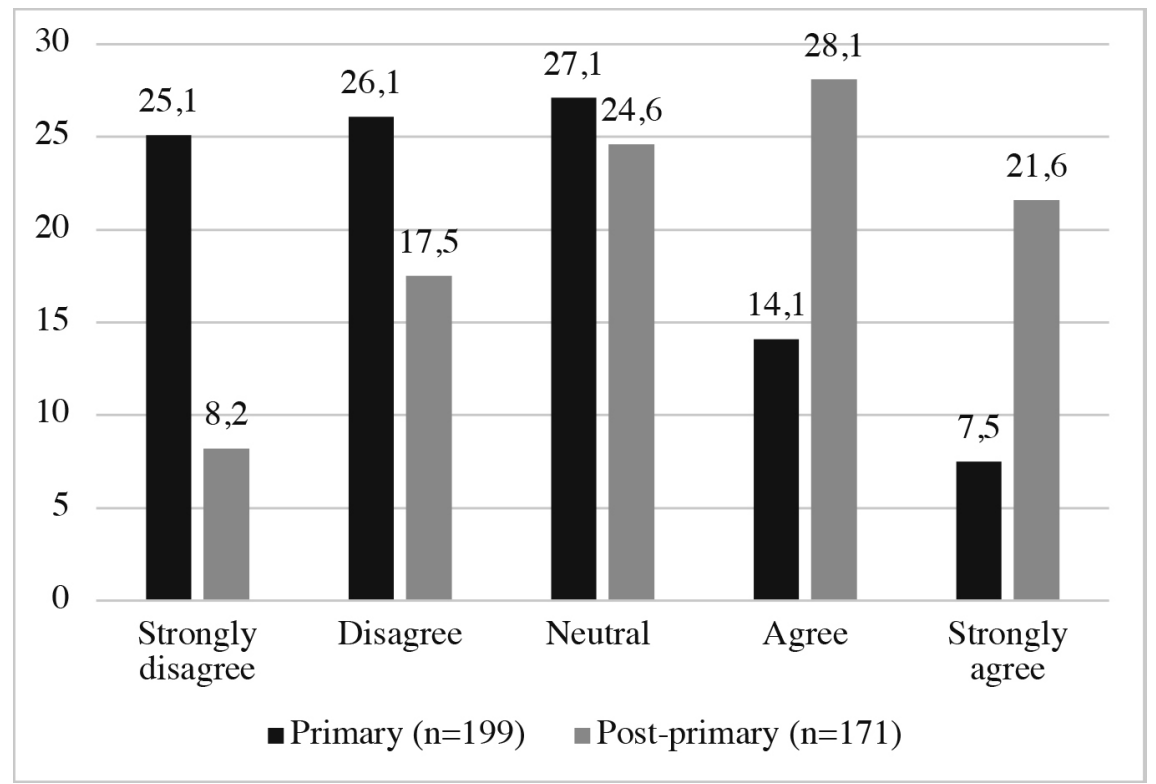

Figure 2. Student responses to the statement: "To be honest, I don't make much effort to speak Irish outside of the class when I am at school."

The responses of the post-primary students are probably not surprising given that their counterparts at a similar age, who live in bilingual 
communities known as Gaeltachtaí, were also found to socialise predominantly through the medium of English, even in cases where Irish was their home language (Ó Giollagáin, Mac Donnacha, Ní Chualáin, Ní Shéaghdha, \& O'Brien, 2007). Students in Ó Cathalláin's (2011) study of Irish-medium schools also reported resistance to the requirement to speak Irish.

At the micro level, Irish-medium schools provide a strong context to support Irish-language competence and use, but students are influenced by wider macro level factors such as the low status of Irish, lack of exposure to Irish in the community and peer-group norms which favour socialisation through English. These issues reflect the unequal power relations between majority and minority languages noted in other contexts (May, 2000). Some people might hold out the hope that when the graduates of Irish-medium schools become parents, they will speak Irish to their children and thus create active minority language family units. The analysis of data gathered across a series of studies involving 1,059 Irish-medium school parents and presented below, interrogates this matter further (Ní Chlochasaigh, Shiel, \& Ó Duibhir, 2018; Ní Thuairisg \& Ó Duibhir, 2016; Ó Duibhir et al., 2017). As can be seen in Table 1, $25.6 \%$ of parents spoke 'English only' with their children, $68.6 \%$ spoke 'English and Irish but mostly English', 3.3\% spoke either 'an equal mix of English and Irish', 1.3\% spoke 'Irish and English but mostly Irish', $0.4 \%$ spoke 'Irish only' and a further $0.8 \%$ spoke a language other than English or Irish.

\begin{tabular}{|c|c|}
\hline & \% parents $(\mathrm{n}=1,059)$ \\
\hline English only & $25.6 \%$ \\
\hline English and Irish but mostly English & $68.6 \%$ \\
\hline An equal mix of English and Irish & $3.3 \%$ \\
\hline Irish and English but mostly Irish & $1.3 \%$ \\
\hline Irish only & $0.4 \%$ \\
\hline Other language & $0.8 \%$ \\
\hline
\end{tabular}

Table 1. What language(s) do you speak to your children at home?

ELIA Mon. I, pp. 39-64 DOI: http://dx.doi.org/10.12795/elia.mon.2019.i1.03 
A subset of parents $(n=107,10.1 \%)$ who were graduates of Irishmedium schools was identified. The relationship between parental attendance at an Irish-medium school and parental reports of speaking Irish with their children at home was explored. To achieve this, the first two categories ('English only' and 'English and Irish but mostly English') were combined into one set, and the remaining categories ('an equal mix of English and Irish', 'Irish and English but mostly Irish', and 'Irish only') into another. The actual language practices of these parents (Table 2), revealed that $12.1 \%(n=13)$ spoke an equal mix of Irish and English, mostly Irish, or only Irish to their children. The remaining $87.9 \%(n=94)$ spoke mostly or only English. If we assume no influence of attendance at an Irishmedium school, we would expect the result to mirror those of the entire population.

\begin{tabular}{|c|c|c|}
\hline \multicolumn{2}{|c|}{ Languages spoken to children at home } & $\begin{array}{l}\text { Attended primary or post- } \\
\text { primary Irish-medium school }\end{array}$ \\
\hline \multirow{4}{*}{$\begin{array}{c}\text { 'English only' or } \\
\text { 'English \& Irish but } \\
\text { mostly English' } \\
\text { 'equal mix of English \& } \\
\text { Irish', 'Irish \& English } \\
\text { but mostly Irish', or 'Irish } \\
\text { only' }\end{array}$} & Count & 94 \\
\hline & Expected Count & 101.6 \\
\hline & Count & 13 \\
\hline & Expected Count & 5.4 \\
\hline \multirow{2}{*}{ Total } & Count & 107 \\
\hline & Expected Count & 107 \\
\hline
\end{tabular}

Table 2. Crosstabulation between parental attendance at Irish-medium school and language spoken to children in the home

A chi-square test was conducted to examine the relation between parents' attendance at an Irish-medium primary or post-primary school and the language they speak to their children at home. The relationship between these variables was statistically significant, $\chi 2(1, \mathrm{~N}=1050)=12.54, \mathrm{p}<$ .001 , with a weak effect size $\varphi c=.109, \mathrm{p}<.001$. This indicates that attendance at an Irish-medium school may contribute to intergenerational Irish language transmission, albeit with a small effect. It is questionable 
whether this could generate enough critical mass on its own to sustain an Irish-speaking community.

In the Ó Duibhir et al. (2017) study, we also investigated the impact of the language spoken in the home on primary and post-primary Irishmedium students $\left(n=370^{1}\right)$ attitude and motivation to learn, and use of Irish across these five scales - 'Desire to learn Irish', 'Attitude to learning Irish', 'Encouragement from parents to learn Irish', 'Self-concept of ability in Irish' and 'Use of Irish'. Use of Irish in the home was found to have a positive impact on student attitude and motivation across the five scales. 'Use of Irish' had a lower mean score than "desire to learn Irish" regardless of the amount of Irish spoken in the home. When scores for these two scales were explored by student age, 'desire to learn Irish' showed minimal variation across different age groups, while scores for 'use of Irish' decreased substantially for the post-primary students compared to the primary students.

One explanation for this is that the strong model of bilingual education in Irish-medium schools, with a high percentage of instructional time in the target language, motivates the primary school students to learn Irish and to use it to some extent. As students enter adolescence, the macro level factors at a societal level have a greater impact on their language practices. Limited exposure to Irish in the media, at home and in wider society and adolescent identity negotiation, draws them to become invested in the dominant language culture. In this scenario, the role for Irish language outside of the sphere of education and examinations diminishes and losses status.

\section{Discussion and Conclusion}

Minority language revitalisation has enjoyed varied success in different jurisdictions. Bilingual education plays a vital role in building a new generation of competent minority language speakers with minority language competence, but this will not necessarily translate into language use in society. Cenoz's Continua of Multilingual Education Model, and Grin's model of competence, opportunity and desire, offer useful insights to aid our understaning of the complex nature of the wider sociolinguistic context. In bilingual communities, students are more likely to speak the

ELIA Mon. I, pp. 39-64 DOI: http://dx.doi.org/10.12795/elia.mon.2019.i1.03 
minority language outside of school compared to students who are not exposed to the language outside the school setting. Exposure to the minority language in the home and community offers opportunities for active bilingualism. When there is no prospect of using the minority language even in a private domain, it is very difficult for young people to negotiate a bilingual identity.

The gap between minority language competence and use is better understood when the wider macro and micro sociolinguistic factors are considered. The population data presented above showed considerable variation by jurisdiction. In the Valencian Community, where a strong multilingual school policy is in place, linguistic distance between Valencian and Spanish is narrow and Valencian speakers are plentiful, the competenceuse gap is relatively small. The case with Irish language is in stark contract. Irish-medium students while competent communicators in Irish, demonstrate a large competence-use gap. When such a gap exists, it is likely that multiple sociolinguistic factors are at play. Irish is rarely spoken in the student's home or community and does not feature widely in the media. Hence it has a low status in society and tends to be marginalised. Irish differs from English in aspects such as syntax, gender and grammatical structure while sharing some alphabetic and phonological aspects, so the distance between the languages is wide. Positive attitudes to learning a minority language are fostered in schools, but as we have seen, the reasonable levels of competence achieved do not always translate into use. This is almost certainly due to a lack of opportunity to use the language socially, which inevitably devalues the status of the language and diminishes linguistic identity.

Linguistic, ethnic and cultural identity are important aspects of the emerging self. In primary school, students conform more readily to teacher expectations. However, in adolescence, students are negotiating their identity. This complex stage of development brings about competing desires to conform with peers and to rebel against systems. Attitudes, belief and values are being formed. The status of the minority language within the home, community and wider society can have a profound impact on linguistic identity. If the language brings minimal added capital or benefit at best, or embarrassment or shame at worst, the motivation to invest in learning and speaking the language will be reduced. Without motivation, students will not develop a positive attitude towards the use of the language.

ELIA Mon. I, pp. 39-64 DOI: http://dx.doi.org/10.12795/elia.mon.2019.i1.03 
If we view minority language programmes in schools as a form of intervention to reverse language shift, it becomes clear that they will only enjoy limited success if we fail to recognise the wider micro and macro contexts. The jurisdictions examined in this paper share many common features in their school minority language programmes. What distinguishes them in terms of the wider use of the minority language in society are the micro factors in the home and community, and the macro factors at a societal level. Where the competence-use gap is smaller, there are greater opportunities to use the minority language for meaningful communication in society. If these conditions are not present in the community and wider society then intervention is required at this level also.

Attempts to force adolescents to adopt a minority language identity are unlikely to be successful. Ideally, they would be encouraged to develop a holistic identity to include dual minority and majority language identities. Because the school is associated with authority in the eyes of students, it is probably not the best context for adolescents to negotiate their identities. This points to the need to broaden revitalisation efforts beyond the school. For teenage students of marginalised languages, exposure to other language minority cultures and contexts may compensate to some degree, for the impoverished linguistic environment they experience beyond the school. This may help them gain a greater appreciation of their minority identity.

Successful intervention beyond the school will only happen where there is an adequately resourced and implemented comprehensive language strategy. Each of the jurisdictions examined above have official language strategies in place. These strategies enjoy varying degrees of success (see Williams, 2013 for a comprehensive review). Where they are successful, they are evidence-based, well planned, monitored, evaluated and resourced. In the case of Ireland, the 20-Year Strategy for the Irish Language 20102030 (Government of Ireland, 2010) is based on rhetoric, is poorly resourced, contains unrealistic targets and is disproportionally focused on revival efforts in education (Ó Duibhir, 2012). The macro and micro contexts discussed above are superficially discussed, but largely ignored in terms of focused evidence-based interventions and achievable outcomes. While minority language education is necessary for language revitalisation, it is not sufficient to increase active bilingualism. Changing linguistic behaviour and normalising use of the minority language outside the sphere of education requires more complex interventions.

ELIA Mon. I, pp. 39-64ＤOI: http://dx.doi.org/10.12795/elia.mon.2019.i1.03 


\section{Notes}

1199 primary (10-11 yr old) and 171 (15-16 yr old) post-primary students.

\section{References}

Baker, C. (2003). Education as a site of language contact. Annual Review of Applied Linguistics, 23, 95-112. https://doi.org/10.1017/S0267190503000217

Baker, C., \& Wright, W. E. (2017). Foundations of bilingual education and bilingualism (6th ed.). Bristol: Multilingual Matters.

Ballinger, S. (2017). Examining peer language use and investment in a distinct North American immersion context. International Multilingual Research Journal, 11(3), 184-198. https://doi.org/10.1080/19313152.2017.1330066

Basque Government. (2016). VI. Inkesta soziolinguistikoa Euskal Autonomia Erkidegoa [Sociolinguistic survey of the Basque Autonomous Community. Retrieved from http://www.euskadi.eus/contenidos/informacion/ikerketa soziolinguistikoak/eu_def/adjuntos/VI_INK_SOZLG_EAE_Aurkezpen_ publikoa_20161014.pd $\overline{d f}$

Busch, B. (2011). Trends and innovative practices in multilingual education in Europe: An overview. International Review of Education, 57(5/6), 541549.

Cenoz, J. (2009). Towards multilingual education: Basque educational research in international perspective. Buffalo, N.Y: Multilingual Matters.

Cenoz, J., \& Gorter, D. (2017). Minority languages and sustainable translanguaging: Threat or opportunity? Journal of Multilingual and Multicultural Development, 1-12. https://doi.org/10.1080/01434632.2017.1284855

Cenoz, J., \& Gorter, D. (2019). Educational policy and multilingualism. In D. M. Singleton \& L. Aronin (Eds.), Twelve lectures on multilingualism (pp. 101132). Bristol: Multilingual Matters.

Central Statistics Office. (2017). Census 2016 summary results - Part 1. Retrieved from https://www.cso.ie/en/media/csoie/releasespublications/documents/ population/2017/7._The_Irish_language.pdf

ELIA Mon. I, pp. 39-64 DOI: http://dx.doi.org/10.12795/elia.mon.2019.i1.03 
Darvin, R., \& Norton, B. (2015). Identity and a model of investment in applied linguistics. Annual Review of Applied Linguistics, 35, 36-56. https://doi. org/10.1017/S0267190514000191

Dołowy-Rybińska, N. (2016). Language attitudes and community engagement: Diwan-The Breton immersion high school through the eyes of its pupils. Journal of Language, Identity \& Education, 15(5), 280-292. https://doi.org $/ 10.1080 / 15348458.2016 .1213134$

Eckert, P. (1988). Adolescent social structure and the spread of linguistic change. Language in Society, 17(2), 183-207. https://doi.org/10.1017/ S0047404500012756

Fishman, J. A. (1991). Reversing language shift. Clevedon: Multilingual Matters.

Fishman, J. A. (2013). Language maintenance, language shift, and reversing language shift. In T. K. Bhatia \& W. C. Ritchie (Eds.), Handbook of Bilingualism and Multilingualism (pp. 466-494). Somerset: Wiley.

Generalitat Valenciana. (2015). Knowledge and social use of the Valencian language: General survey 2015, Synthesis of results. Valencia: Consellaria D’Educació, Investigació, Cultura I Esport.

Government of Ireland. (1987). Second joint report on the Irish language. Dublin: The Stationery Office.

Government of Ireland. (2010). 20-year strategy for the Irish language 20102030. Dublin: Stationery Office.

Grin, F. (2003). Language policy evaluation and the European Charter for Regional or Minority Languages. Basingstoke: Palgrave Macmillan.

Groff, C., Pilote, A., \& Vieux-Fort, K. (2016). "I am not a Francophone”: Identity choices and discourses of youth associating with a powerful minority. Journal of Language, Identity \& Education, 15(2), 83-99. https://doi.org/1 $0.1080 / 15348458.2015 .1137476$

Hinton, L. (2011). Language revitalization and language pedagogy: New teaching and learning strategies. Language and Education, 25(4), 307-318. https:// doi.org/10.1080/09500782.2011.577220

ELIA Mon. I, pp. 39-64 DOI: http://dx.doi.org/10.12795/elia.mon.2019.i1.03 
Hornberger, N. H. (2008). Can schools save indigenous languages? Policy and practice on four continents. Basingstoke: Palgrave Macmillan.

Landry, R., Allard, R., \& Deveau, K. (2010). Schooling and cultural autonomy: A Canada-wide study in Francophone minority schools. Québec: Canadian Heritage and Canadian Institute for Research on Linguistic Minorities.

Manterola, I. (2013). And if we add the didactics of language leg to the table? In I. Martínez de Luna, P. Suberbiola, M. Zalbide, A. Egaña, \& E. Ubieta (Eds.), Talking pupils, the Arrue Project 2011: Research results and contributions of experts (pp. 287-291). Vitoria-Gasteiz: Department of Education, Language Policy and Culture of the Basque Government and The Sociolinguistics Cluster.

Manterola, I., Almgren, M., \& Idiazabal, I. (2013). Basque L2 development in immersion school settings. International Journal of Bilingualism, 17(3), 375-391. https://doi.org/10.1177/1367006912438996

Martínez de Luna, I., Suberbiola, P., Zalbide, M., Egaña, A., \& Ubieta, E. (2013). Talking pupils, the Arrue Project 2011: Research results and contributions of experts. Retrieved from http://www.soziolinguistika.eus/files/talking pupils.pdf

May, S. (2000). Uncommon languages: The challenges and possibilities of minority language rights. Journal of Multilingual and Multicultural Development, 21(5),366-385.https://doi.org/10.1080/01434630008666411

McCarty, T. L. (2008). Schools as strategic tools for indigenous language revitalization: Lessons from native America. In N. H. Hornberger (Ed.), Can schools save indigenous languages? Policy and practice on four continents (pp. 161-179). Basingstoke: Palgrave Macmillan.

National Records of Scotland. (2013). 2011 Census: Key results on population, ethnicity, identity, language, religion, health, housing and accommodation in Scotland - Release 2A. Edinburgh: Scottish Parliament Retrieved from https://www.scotlandscensus.gov.uk/documents/censusresults/release2a/ StatsBulletin2A.pdf.

National Records of Scotland. (2014). 2011 Census: Statistical bulletin 2. Edinburgh: Scottish Parliament Retrieved from https://www.scotlandscensus. gov.uk/documents/censusresults/release2/statsbulletin2.pdf.

ELIA Mon. I, pp. 39-64 DOI: http://dx.doi.org/10.12795/elia.mon.2019.i1.03 
Ní Chlochasaigh, K., Shiel, G., \& Ó Duibhir, P. (2018). Tionchar an tumoideachais ar dhaltai i scoileanna lán-Ghaeilge le stádas DEIS: Gnóthachtáil, dearcthai agus dúshláin [The impact of immersion education on students in Irish-medium DEIS schools: Achievement, perspectives and challenges]. Paper presented at the The Second All-Ireland Research Conference on Immersion Education, Mary Immaculate College, Limerick.

Ní Thuairisg, L., \& Ó Duibhir, P. (2016). An leanúnachas ón mbunscoil go dtí an iar-bhunscoil lán-Ghaeilge i bPoblacht na hÉireann. Retrieved from http:// www.gaelscoileanna.ie/files/An-Lean--nachas-on-mbunscoil-go-dt---aniar-bhunscoil-1--n-Ghaeilge-_MF-2016.pdf

Norton, B. (2013). Identity and language learning: Extending the conversation (2nd ed.). Bristol: Multilingual Matters.

Ó Cathalláin, S. (2011). Early literacy in all-Irish immersion primary schools: A micro-ethnographic case study of storybook reading events in Irish and English. (PhD), University of Stirling,

Ó Duibhir, P. (2012). Cúrsaí oideachais agus Straitéis 20 Bliain don Ghaeilge [Education matters and the 20-Year Strategy for Irish]. In C. Lenoach, C. Ó Giollagáin, \& B. Ó Curnáin (Eds.), An chonair chaoch: An mionteangachas sa dátheangachas (pp. 269-283). Gaillimh: Leabhar Breac.

Ó Duibhir, P. (2018). Immersion education: Lessons from a minority language context. Bristol: Multilingual Matters.

Ó Duibhir, P., Ó Cathalláin, S., NigUidhir, G., Ní Thuairisg, L., \& Cosgrove, J. (2017). An analysis of models of provision for Irish-medium education. Retrieved from https://www.forasnagaeilge.ie/analysis-models-provisionirish-medium-education/?lang=en

Ó Giollagáin, C., Mac Donnacha, S., Ní Chualáin, F., Ní Shéaghdha, A., \& O'Brien, M. (2007). Comprehensive linguistic study of the use of Irish in the Gaeltacht. Dublin: Department of Community, Rural and Gaeltacht Affairs.

Ó Riagáin, P. (2018). Measures of language proficiency in censuses and surveys: a comparative analysis and assessment. Basingstoke, Hampshire: Palgrave Macmillan.

ELIA Mon. I, pp. 39-64 DOI: http://dx.doi.org/10.12795/elia.mon.2019.i1.03 
Pavlenko, A., \& Blackledge, A. (2004). Introduction: New theoretical approaches to the study of negotiation of identities in multilingual contexts. In A. Pavlenko \& A. Blackledge (Eds.), Negotiation of identities in multilingual contexts (Vol. Negotiation of identities in multilingual contexts, pp. 1-33). Clevedon: Multilingual Matters.

Pavlenko, A., \& Norton, B. (2007). Imagined communities, identity, and English language learning. In J. Cummins \& C. Davison (Eds.), International Handbook of English Language Teaching. Springer International Handbooks of Education, vol 15 (pp. 669-680). Boston, MA: Springer.

Price, A. R., \& Tamburelli, M. (2016). Minority language abandonment in Welshmedium educated L2 male adolescents: classroom, not chatroom. Language, Culture and Curriculum, 29(2), 189-206. https://doi.org/10.108 0/07908318.2015.1136323

Riestenberg, K., \& Sherris, A. (2018). Task-based teaching of indigenous languages: Investment and methodological principles in Macuiltianguis Zapotec and Salish Qlispe revitalization. The Canadian Modern Language Review, 74(3), 434-459. https://doi.org/10.3138/cmlr.4051

Roberts, A. (2019). Commissioner to focus on bridging education and employment. Retrieved from http://www.comisiynyddygymraeg.cymru/english/news/ Pages/Commissioner-to-focus-on-bridging-education-and-employment. aspx

Skutnabb-Kangas, T. (2008). Language rights and bilingual education. In J. Cummins \& N. H. Hornberger (Eds.), Encyclopedia of Language and Education, Volume 5: Bilingual Education (2nd ed., pp. 117-132). Netherlands: Springer Science.

Soziolinguistika Klusterra. (2017). Hizkuntzen erabileraren kale-neurketa. Euskal Herria, 2016 [Language use on the street: Basque Country, 2016]. In. Retrieved from http://www.soziolinguistika.eus/files/hekn2016-_eu_1.pdf

Stern, A. J. (2017). How Facebook can revitalise local languages: Lessons from Bali. Journal of Multilingual and Multicultural Development, 38(9), 788796. https://doi.org/10.1080/01434632.2016.1267737

Thomas, E. M., Apolloni, D., \& Lewis, G. (2014). The learner's voice: Exploring bilingual children's selective language use and perceptions of minority

ELIA Mon. I, pp. 39-64 DOI: http://dx.doi.org/10.12795/elia.mon.2019.i1.03 
language competence. Language and Education, 28(4), 340-361. https:// doi.org/10.1080/09500782.2013.870195

Thomas, E. M., \& Roberts, D. B. (2011). Exploring bilinguals' social use of language inside and out of the minority language classroom. Language and Education, 25(2), 89-108.

https://doi.org/10.1080/09500782.2010.544743

Thordardottir, E. (2011). The relationship between bilingual exposure and vocabulary development. International Journal of Bilingualism. https:// doi.org/10.1177/1367006911403202

United Nations. (1966). International Covenant on Civil and Political Rights. In. Retrieved from https://www.ohchr.org/en/professionalinterest/pages/ccpr. aspx

Van Lier, L. (2010). Agency, Self and Identity in Language Learning. In B. O'Rourke \& L. Carson (Eds.), Language learner autonomy: Policy, curriculum, classroom: A Festschrift in honour of David Little (pp. ixxviii). Oxford: Peter Lang.

Welsh Government. (2012). 2011 Census: First Results on the Welsh Language Cardiff: Knowledge and Analytical Services Retrieved from https://gov. wales/docs/statistics/2012/121211sb1182012en.pdf.

Welsh Government. (2018). National survey for Wales, 2017-18 Welsh language: Confidence and attitudes. Cardiff: Statistics for Wales.

Williams, C. H. (2013). Minority language promotion, protection and regulation: The mask of piety. Basingstoke, Hampshire: Palgrave Macmillan.

First version received: July, 2019 Final version accepted: October, 2019

ELIA Mon. I, pp. 39-64 DOI: http://dx.doi.org/10.12795/elia.mon.2019.i1.03 